\title{
DE ESPACIO HETEROLÓGICO A POSICIÓN ESTRATÉGICA: EL PAPEL POLÍTICO DE LA COCINA PAMPINA EN LA MiNERÍA DEL NiTRATO CHILENO. EL CASO DE “LA HUELGA DE LAS COCINAS APAGADAS" (1918-1946)
}

\author{
Sergio González Miranda ${ }^{1}$
}

\section{* Introducción}

\section{Resumen} La cocina en la pampa salitrera, como espacio de sociabilidad y como oficio o labor, a pesar de su importancia en la reproducción de la mano de obra, fue marginalizada y precarizada durante todo el ciclo de expansión del nitrato, hasta que en 1941 se produce la huelga de "las cocinas apagadas" que transformó a la cocina en un lugar visible y estratégico. Se realiza un recuento histórico de la evolución de la industria salitrera, de los movimientos sociales de mujeres y su relación con dos espacios contrapuestos: la pulpería y la cocina, incluyendo en esta última a las habitaciones obreras. Mientras la pulpería fue un espacio público de demandas y conflictos sociales, la cocina fue el espacio privado por antonomasia y relegado al silencio.

Se sostiene que la cocina fue un espacio heterotópico, en el sentido de un espacio diferente, siguiendo el pensamiento de Michel Foucault, y fue un espacio heterológico, en tanto lugar y labor supuestamente improductivos dentro de la industria del salitre.

Palabras claves: cocina pampina - espacio heterológico - posición estratégica - movimientos de mujeres - salitreras.

\begin{abstract}
The kitchen in the saltpeter (nitrate) pampa, as a social and work space, despite its significance in the reproduction of the labor force, was marginalized and jeopardized during the whole nitrate expansion cycle, until in 1941 when the strike of the "closed kitchens" transformed the kitchen into a visible and strategic place. In this article we present a historic recount of the evolution in the nitrate industry, women's social movements and its connections with two opposed spaces: the pulpería (grocery store) and the kitchen, the latter was part of the worker's rooms. While the pulpería was a public space for demands and social conflicts, the kitchen was a private, calm and silent space. It is argued that the kitchen was a heterotopic space, as in a different space, following Michel Foucault's thinking. It also was a heterological space, and supposedly unproductive in the nitrate industry.
\end{abstract}

Key words: the kitchen of the pampa salitrera- heterological space - strategic position - women's social movements - nitrate mines.
La cocina pampina no fue una utopía. La cocina pampina fue un espacio o lugar concreto donde trabajaron generaciones de mujeres desde el inicio del ciclo del salitre en las primeras décadas del siglo XIX en Tarapacá hasta décadas después de terminada la fase de expansión de dicho ciclo en todo el territorio comprendido entre Pisagua y Taltal. La cocina pampina no fue un espacio soñado que se transformó en realidad, al contrario, fue un espacio que surgió por la necesidad de esta minería antes que fuera transformada en industria. Probablemente, las primeras cocinas pampinas fueron espacios abiertos, donde el fogón fue construido de costra, barro y chuca, ocupando un lugar provisional, teniendo por escenario el desierto.

Sin hacer referencias a la etapa de cateos, los primeros campamentos salitreros fueron temporales porque la explotación del nitrato fue a baja escala, ese período es conocido en la minería del salitre como "de paradas" (Hernández 1930; Bermúdez 1963). Las primeras mujeres que se ocuparon de los oficios relacionados a la cocina pampina, en esa primera etapa, difícilmente lo hicieron en el contexto de una familia, porque el censo peruano de 1841 registra escasos habitantes en la pampa, reconociendo - sin embargo- la existencia de salitreras. Posiblemente la población al momento del censo se regresaba a los lugares que consideraban sus verdaderas casas en los valles precordilleranos de la provincia.

1 Instituto de Estudios Internacionales de la Universidad Arturo Prat. Casilla 121, Iquique, Chile. Email: pampino@gmail.com. 
Haciendo una revisión general del censo peruano de 1841 de Tarapacá, observamos que los poblados de los valles precordilleranos concentraban la mayor parte de la población provincial, a saber: Tarapacá $(32,4 \%)$, Guaviña $(6,3 \%)$, Coscaya $(4,0 \%)$, Loanzana $(5,1 \%)$, Mamiña $(14,2 \%)$, Macaya $(3,9 \%)$, Parca $(5,1 \%)$, entre otros. Los puertos estaban en crecimiento, como era el caso de Iquique (12,6\%), la minería tradicional argentífera en el proceso contrario: Santa Rosa (10,6\%) y Huantajaya $(5,7 \%)$. La minería emergente del salitre se ubicaba en el piedemonte oriental de la Cordillera de la Costa, aledaña a la pampa del Tamarugal que, con sus tamarugos, proporcionaba la energía necesaria para los fogones. En este censo sólo se menciona a "Pozos" (sin habitantes) y "Salitrera" $(0,1 \%)$, como conceptos genéricos.

Se puede concluir que no había campamentos estables que pudieran ser considerados por los pampinos como sus hogares. Eran por lo mismo pequeños asentamientos humanos temporales, que duraban hasta cuando se agotaba el caliche de alta ley que era lixiviado en fondos, primero de cobre y después de fierro fundido. Las viviendas eran, por lo mismo, muy precarias: tal como lo señala John H. Blake en su informe de 1838 , estaban construidas las paredes con una mezcla de arcilla y ripio, mientras "los techos eran de paja sobre vigas de cactus" (Crozier 1997: 62). Todavía no existían estaciones de ferrocarril y los pueblos, como La Noria, Cocina, Rinconada, entre otros, no distaban mucho de esa realidad constructiva. Sin embargo, resulta sorprendente que casi un siglo después, en 1930, ya concluido el ciclo de expansión del salitre, durante el gobierno de Carlos Ibáñez del Campo, cuando la Asociación de Productores de Salitre de Chile inicia un nuevo proyecto de construcción de viviendas, se argumenta que no se realizaron con anterioridad estas modificaciones porque: "hasta hace pocos años prevaleció en la Pampa el sistema de explotación en pequeña escala, lo que dio origen a la instalación de pequeñas plantas u Oficinas de proporciones reducidas que empleaban escaso número de obreros, porque los terrenos de beneficio eran de duración limitada" (Macuer Llaña 1930: 238). Argumentación completamente falsa considerando el tamaño de la mayoría de las oficinas salitreras que comenzaron a surgir en la década de 1870 en Tarapacá ${ }^{\text {(Billinghurst }}$

\footnotetext{
2 Efectivamente, mientras el proceso de lixiviación -con el sistema
}

1889: 51), y por el desarrollo de los materiales de construcción hacia 1930.

La pampa salitrera se caracterizó por sus flujos de modernidad a través de bienes venidos de ultramar y de flujos transfronterizos por medio de mercancías tradiciones. Estos flujos generaron lugares no homogéneos como lo fueron los cantones (González-Artaza 2013: 325 ss.). No existe un cantón salitrero igual a otro desde Pisagua hasta Taltal. El desierto en sí mismo es una ruptura de lo que se podría definir como "lo cotidiano", al salir más allá de las fronteras del campamento y, con mayor razón aún, de las del cantón, se corría el riesgo de "empamparse", término que se refiere al riesgo de perderse en la pampa, temor que no era exclusivo de los "recién llegados" o enganchados. Es decir, era una definición del desierto como extraño, ajeno y misterioso, una discontinuidad y límite entre lo conocido y lo desconocido.

En los cantones, con sus pueblos y campamentos, el desierto se fue llenando de lugares heterotópicos y sus complejidades culturales, sea por las migraciones, la confluencia de bienes llegados desde la modernidad o la tradición, las tecnologías diversas, el contraste del desierto con las actividades humanas, etc. Incluso los pueblos podrían ser calificados, siguiendo la mirada de Foucault, como la "otra ciudad", en el sentido que allí se ubicaron no sólo el comercio sino las salas de juego y casas de prostitución, migrantes asiáticos y europeos en una tensa convivencia, los gremios, los hoteles, la policía y las parroquias, entre otras actividades, donde también trabajaron mujeres. Como muy bien lo recuerda el escritor y pampino Homero Bascuñán, los pueblos del salitre eran una prolongación de las estaciones del ferrocarril:

"Las mujeres trabajaban en los restaurantes y en las cocinerías instaladas al borde de la línea, donde vendían pescado frito, sándwiches, empanadas y huevos duros a los viajeros. Es claro que alli había otras -como en todas partes- que hacían lo suyo en los lupanares. Perdónenme quienes me lean si toco este punto tan escabroso, pues no lo hago con el bajo propósito de refocilarme

de vapor-comenzó a industrializarse rápidamente a partir del boom salitrero de mediados de la década de 1870 y, con mayor razón aún con la introducción generalizada del sistema Shanks una década después, surgieron salitreras de gran tamaño y, por lo mismo, con campamentos estables y bien organizados como se puede observar en el álbum fotográfico de Boudat (1889). 
con sus recuerdos mientras escribo. Sólo quiero esbozar la estampa de algunas de aquellas pobres mujeres caminando apenas por las huellas desérticas de la Pampa, vencidas, sin trabajo, después de los días tan tristes y amargos que trajo la crisis..." (Bascuñán 1976: 290).

Los pueblos del desierto eran la otredad, en el sentido que lo describe Foucault: "Estos lugares, porque son absolutamente otros que todos los emplazamientos que reflejan y de los que hablan, los llamaré, por oposición a las utopías, las heterotopías..." (1994: 71).

Este autor identifica diversos espacios heterotópicos, como los de crisis, sean sagrados o prohibidos, o de desviación (1994:72). El espacio heterotópico de la cocina pampina no cabe en ninguna de las definiciones que establece este autor en su famoso escrito sobre los "lugares diferentes"s. Se trata de un espacio que, sin ser sagrado, prohibido o desviado, era diferente, dominio propio de las mujeres, algo oculto a la mirada del extraño, donde además se realizaba una transmisión de saberes culinarios. Si bien su ubicación, en el marco de la economía salitrera, era marginal, había un reconocimiento cultural sobre esos saberes (Sánchez 2013).

Las mujeres mismas fueron un recurso escaso y extraño en la pampa salitrera. La población femenina fue siempre menor respecto de la masculina y, por lo mismo, su vida cotidiana en algunos campamentos fue más riesgosa, obligando a las mujeres solas a refugiarse en oficios o labores domésticas. Veamos el extracto de una carta de una pampina llamada Manuela Lanchipa a su esposo, Agustín Oxa, escrita en la Oficina Salitrera Constancia en 1896:

"Mi querido Agustín deseo que te alles bueno como io lo deseo, quedando io buena a tus ordenes, recibi tu carta fecha 6 del presente día 8 de lo que quedo enterada de todas las refleciones que me ases, todo está bien yo no me aparto de corazón o si ahora me abandonaste bien echo que page mi desobediensia, para que otra bes obedesca lo que me mandes, en fin todo está bien, el sentimiento no se me borrará de lo que tu me has dejado abandonada en una oficina como me dejaste, al berme sola abandonada tube que (ilegible en el orginal) entrar a labar en la casa, estoi desde el

3 Conferencia en el Círculo de Estudios Arquitectónicos, 14 de marzo de 1967: "Des espaces autres", publicada en español como "Espacios diferentes". Ver Focault 2010.

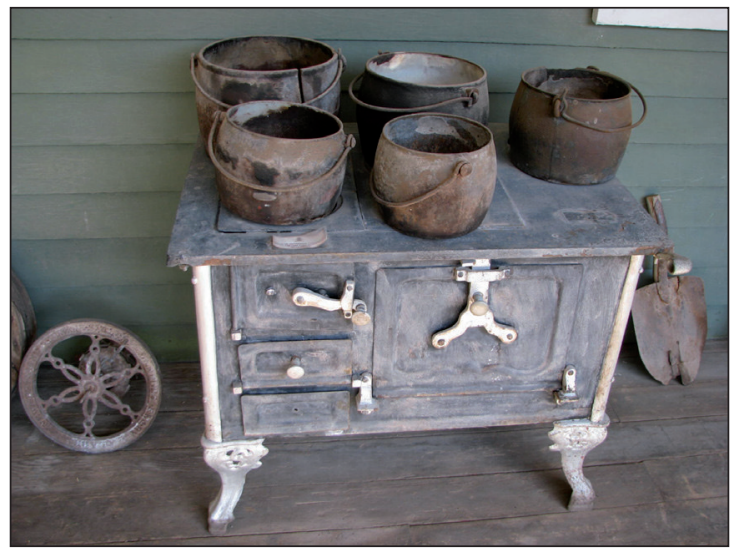

Figura 1. Cocina, Museo Peña Grande.

día 6 i qué esperaba que me isieran pasar alguna berguenza por la pieza, eso me obligó que entrara pronto..." (González 2006: 794).

El esposo la dejó en la mencionada salitrera mientras él partió a buscar trabajo en otras oficinas, lo que le obligó a ella entrar a lavar en una casa, entre otras razones para que no le quitaran la pieza donde vivía, y porque una mujer sola en el campamento era un riesgo.

La tecnología salitrera fue un ámbito privilegiado para la ingeniería y la química, en los procesos de instalación de maquinarias, construcción de campamentos y ferrocarriles, pero preferentemente en la elaboración de salitre y yodo, ${ }^{4}$ empero ese ímpetu tecnológico no alcanzó a todas las faenas y oficios de igual modo. El paso del cateador al ingeniero y del cortador de yodo al químico no fue inmediato, dependió de la escala de industrialización de cada oficina salitrera. Quedaron siempre y hasta el fin del ciclo, oficios y actividades que no se modificaron mayormente desde los orígenes de esta economía, como el caso de la cocina pampina. Si bien por el transporte marítimo venido desde Europa y Norteamérica llegaron cocinas modernas de fierro (Figura 1), que se ofrecían en la prensa de la época, por las características de los contratos precarios que los obreros acordaban con las administraciones, especialmente los particulares que eran la gran mayoría de la fuerza de trabajo salitrera, no era recomendable tener

4 Ronald Crozier entrega importantes antecedentes de este cambio tecnológico del paso del sistema de "paradas" al de "máquinas" (1997: 64 ss.). 
bienes muebles puesto que la estadía en las oficinas generalmente era temporal.

Tanto la comida como el agua fueron la base del consumo en un entorno desértico, por lo que fue fundamental la dependencia de los primeros campamentos salitreros del abastecimiento de comida y agua desde los valles precordilleranos de la provincia, incluida la mano de obra. Por lo mismo, la dieta de los mineros del salitre si bien pudo asemejarse a la de los mineros de Atacama en general (Páez 2000), debió estar influida por la tradición culinaria criolla de estos pueblos de los valles tarapaqueños y de las comunidades andinas, desde donde llegaría carne y charqui de camélidos a los pueblos del desierto.

Cuando la economía del salitre inició su fase de industrialización, algunas actividades como las cocinerías, fueron escasamente reguladas dentro el proceso industrial de producción del nitrato de soda. Por lo que la cocina quedó como una actividad dejada a la iniciativa privada pero dentro de los campamentos. A diferencia del abastecimiento de agua que estuvo siempre bajo administración de las compañías salitreras desde que comenzaron a construirse los pozos en determinados lugares del desierto, los que recibirán el nombre de donkey cuando se utilizaron animales para la extracción de este vital recurso.

Como comentábamos, los cambios tecnológicos en la minería del salitre se concentrarán principalmente en el proceso de lixiviación del nitrato de soda, secundariamente en el transporte, especialmente desde y hacia los puertos de embarque, quedando el proceso de extracción en un menor desarrollo. Los servicios también tuvieron un desarrollo diverso, como veremos más adelante, por ejemplo, entre la pulpería y la cocina.

El impacto social de la innovación tecnológica en el proceso de industrialización del salitre vino a observarse en Tarapacá en el censo peruano de 1866, pues sus habitantes llegaron a los 9646 y, de ellos, "3.249 personas fueron censadas en la ciudad de Iquique (33.7\%), y 498 en las Oficinas y pueblos salitreros (5.2\%). La población censada en el espacio andino (valles, precordillera y altiplano) fue de 5.899 personas, los que representan el 61.1\% provincial" (Ruz et al. 2008: 31). En este censo se hace referencia a los cantones de Negreiros, Ramírez y La Peña. Lo que demuestra un cambio de un patrón de ocupación en transi-

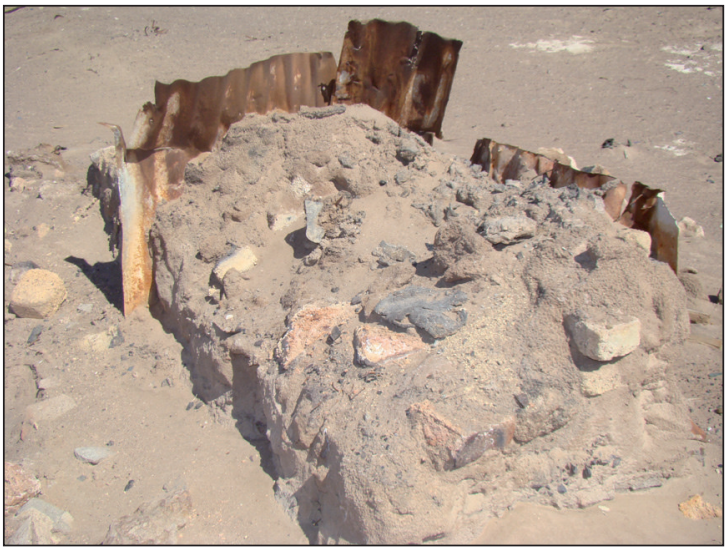

Figura 2. Cocina, campamento Don Guillermo.

ción a otro permanente, donde los campamentos pasan a ser verdaderos asentamientos humanos, articulados además con pueblos del desierto y puertos de embarque, generando un proceso de urbanización (González 2013: 218 ss.), que se vería acentuado con el gran cambio tecnológico generado por el sistema de lixiviación Shanks, especialmente después de la Guerra del Pacífico. Sin embargo, se puede observar en las ruinas de los campamentos de todos los cantones de las regiones salitreras, una escasa innovación técnica en la construcción de las cocinas (Figuras 2 y 3 ).

Las imágenes de las ruinas salitreras no se refieren al período de "paradas", sino al que se vivió al final del ciclo de expansión del salitre. Se observa un grupo de cocinas construidas con barro, calaminas y ladrillos, además se pueden ver algunas piedras de moler. Solamente en Antofagasta con la administración norteamericana, bajo el sistema de elaboración Guggenheim, y en Tarapacá bajo la Compañía de Salitres de Chile (CO$\mathrm{SACH}$ ), comenzó la construcción de campamentos salitreros bajo estándares más modernos en las viviendas, incluyendo las cocinas.

En parte, los cambios en las condiciones de vida en la pampa salitrera se debieron a la labor realizada por funcionarios públicos de Oficina del Trabajo. En uno de los informes de Eugenio Frías Collao, jefe de la mencionada oficina, menciona el problema de las habitaciones obreras, a saber:

"El campamento se compone, generalmente, de dos o tres grandes galpones de zinc, divididos interiormente por planchas del mismo 
material en pequeños departamentos de dos piezas cada uno. Los hombres solteros tienen derecho a ocupar una pieza, y las familias un departamento de dos piezas cualquiera sea el número de personas que la componen. Las piezas son bajas, estrechas, sin luz, sin ventilación y carecen de todo servicio higiénico, pues allí el agua es un artículo de lujo, que se vende a un precio fabuloso, y cuyo uso es estrictamente limitado a las necesidades indispensables. Todavía los galpones de zinc constituyen un progreso evidente, pues aún hoy día lo que se llama habitaciones en algunas Oficinas, son verdaderas cuevas formadas con pedazos de costra y cubiertas exteriormente con sacos viejos, trapos sucios y toda clase de desperdicios" (Frías 1911: 18).

Comparemos este relato con el recuerdo de una pampina que vivió en el cantón de Negreiros en pleno auge del salitre, la señora Cristina Guzmán, cuya familia era originaria de Oruro, Bolivia:

"[...] en la oficina Aura, la primera pieza había una mesa y un par de bancas, sobre la mesa una botella con agua y un vaso eso era todo, después un dormitorio, una cocina en pésimas condiciones, las casas eran malas de calaminas. Donde vivimos un poco mejor fue en la oficina Irene, tenía un campamento de 7 casas, al terminar estas tres habitaciones de solteros, había tres calles, la avenida Irene, la calle Santiago y la calle 10 de Julio, de esas tres calles se componía la oficina Irene, era chiquita, pero las casas eran limpiecitas, eran de calaminas, piso de ripio, el techo también de calamina, fueron las mejores casas que yo recuerdo. En Agua Santa había casas de muros de costra, pero nosotros vivíamos en casas de calaminas.

"Yo le voy a conversar lo mala que era la situación antes, yo recuerdo que mi mamá en la oficina Irene tenía de cocina unos tarros cuadrados de manteca, los que llenaban con tierra, les ponían una plancha, después le ponían la costra e iban a buscar ripios, en el ripio venía un material que se llamaba borra, entonces con esa borra tapaban la costra como estucado, enseguida la plancha y la chimenea de calamina, los dueños de casa tenían que estirar las calaminas, las planchaban como podían, esas eran las cocinas que se usaban antes.

"La oficina Irene fue la mejor que yo conocí, como le conversé antes era una corrida de siete casas, un callejón y después venía la

5 Las entrevistas utilizadas en este artículo fueron realizadas entre 1986 y 1990 . Forman parte del archivo Hombres y Mujeres de la Pampa. Ver González, S. 2006. otra corrida por el callejón pasaban mañana y tarde vendiendo el agua, también dos tolvas con dos hombres tirada por un macho, se llevaban la basura y el agua sucia, fue la oficina más limpia e higiénica. En Agua Santa en cambio no, el agua sucia se botaba en la calle, sólo pasaban recogiendo la basura.

"Dentro de la casa en el lugar que se le daba el nombre de cocina, también se lavaba, la gente criaba gallinitas, incluso mi mamá en la oficina Irene tenía hasta cordero ahí en la cocina, no había nada de higiene".

Hemos sostenido que la cocina, en el período de paradas, debió estar ubicada en un espacio abierto, empero cuando se construyeron los primeros campamentos estables la cocina quedó relegada al interior de las casas, a un espacio oculto, íntimo, otro. La cocina pampina, ese otro espacio, también fue un espacio diferente (Foucault 2009: 20) dentro del mismo campamento, pero no tanto en su heterotopía como en su heterología. ${ }^{6}$

\section{* La cocina en el margen. La heterología}

Las cocinerías no fueron las únicas que prestaron servicios no pagados formalmente por las empresas salitreras. Algo similar aconteció con los criadores de cerdos que estaban en las pampas cercanas, cuyo papel fue clave en la alimentación de los trabajadores y sus familias. También los arrieros y mujeres que vendían sus productos de la tierra en las entradas de los campamentos. Un dibujo de Melton Prior de 1889, en su viaje como parte de la comitiva de J. T. North y W. H. Russell, registró a mujeres con sus canastos vendiendo como si fuera una feria andina. Mientras no fueran una competencia para la pulpería, las administraciones toleraban esta práctica comercial que permitía abastecer a la población de algunos productos que sólo era posible adquirir por esa vía, como la chicha de jora o de mucko, las hojas de coca, harinas de maíz, charqui, lanas de camélidos y ovinos, etc., a veces su origen era transfronterizo e ingresado como contrabando?

6 Para Bataille la heterología es la "ciencia de lo que es enteramente otro" (Alcantud 2005: 81).

7 Escrito de la Subdelegación $11^{\text {a }}$ de Tarapacá al Intendente de Tarapacá: "Para informar a Us. sobre el contrabando de salitre, encontrado en la quebrada Honda, estoy esperando los datos que pedíal Señor Inspector del $6^{a}$ Distrito de Mamiña, y saber el resultado del denuncio que debió 
Estas actividades comerciales o de servicios no sólo eran informales sino que podían ser ilegales para la administración de las oficinas y para las autoridades locales. A pesar de ello, todas las salitreras dependieron de esos flujos de mercaderías, incluyendo a la propia mano de obra que llegaba al margen de los enganches formales. ¿Cómo se podían abastecer de hojas de coca los trabajadores bolivianos de origen quechua o aymara?, ¿quiénes podían preparar sus comidas?, la misma pregunta se podría hacer respecto de los trabajadores peruanos, argentinos, chilenos y de otras nacionalidades. Los basurales de la pampa guardan los vestigios del consumo moderno en las oficinas salitreras pero también de ese otro consumo que podemos definirlo de tradicional y campesino, que fue tanto o más masivo. La arqueología ha permitido develar parte del consumo de la población, especialmente de animales como vacunos (Labarca 2009), que era la comida principal en pueblos y campamentos.

Las recuas de mulas y tropas de camélidos (llamas) abastecieron durante casi todo el ciclo de expansión del salitre, generando un circuito transfronterizo que comenzaba, por ejemplo, en algún valle, como el de Cochabamba, y terminaba en la cocina de alguna salitrera de Negreiros. Estas actividades ocuparon espacios periféricos, corrales, tambos, aguadas, llegando incluso a consolidarse como pequeños y marginales asentamientos humanos. Equipos de arqueólogos han realizado importantes estudios de asentamientos humanos que ocuparon zonas periféricas del espacio salitrero, donde el campamento y la planta de lixiviación fueron el centro.

Las oficinas salitreras tuvieron un hinterland donde se desarrollaron actividades asociadas con la economía del salitre, pero con cierta autonomía y escaso reconocimiento por parte de las compañías y sus administra-

hacer al Juez de Distrito para que instruya el sumario correspondiente. En Septiembre 1909 y un oficio $N^{\circ} 54$ dirijido a la Intendencia, esta Subdelegación daba cuenta de los contrabandos de coca, lana, ganado y salitre que se hacían; y pedía fuerza para hacer respetar la Ley; dicha nota, quedó sin contestación. Chusmiza, Cultane, Sibaya, Sotoca, Parca y Mamiña; son los puntos de tránsito para Bolivia y creo que unas parejas de carabineros recorriendo los caminos de Huara a Chusmiza, Tarapacá a Cultane y Tarapacá a Mamiña; cortarían el mal en su raizz" (Archivo de Intendencia de Tarapacá ITAR 824. Libro Subdelegaciones, foja 98, año 1911). ciones, a pesar de su innegable importancia, como fue el aprovisionamiento de agua, de mulares, de alimentos, de ropa para los obreros, etc. En el estudio realizado por los arqueólogos Vilches, Rees y Silva en los cantones El Toco y Pampa Central, identificaron tres categorías de estos asentamientos periféricos, a saber: "fraguas, cocinas-comedor-fragua y campamentos" (2008: 25). Estos investigadores llegan a esa distinción a través de los fragmentos encontrados en los sitios estudiados, lo cual complementa lo sabido desde la historiografía salitrera, donde actividades u oficios como las del "herreropampa", el "donkero-pique", el "porquerizo", el arriero o patrón, etc., se ubicaron en las cercanías de los campamentos pero extramuros. También hubo precarios y temporales asentamientos humanos asociados a la construcción de las líneas férreas, como los tambos que, antes de la llegada del ferrocarril, prestaron servicios a los arrieros que venían allende los Andes, sea de Bolivia o del noroeste argentino.

La fragua, el donkey o pozo de agua, el tambo, los corrales, la cocina. Específicamente nos referimos a esta última. Tampoco se pretende aquí una historia de la mujer en la sociedad del salitre, aunque ella haya sido el sujetootro más notoriamente heterológico, representada en las yerbateras, parteras, lavanderas, nodrizas, y por cierto, en las cocineras. Sujetos relegados al silencio a pesar de sus oficios fundamentales durante el ciclo de expansión del nitrato (ca. 1870-1920). No todos los oficios de las mujeres en la industria del salitre fueron relegados a lo privado, algunas trabajaron en los escritorios como dependientes, en las pulperías como empaquetadoras, en las escuelas como maestras, en el biógrafo como pianistas, etc. Aunque no hayan tenido contrato alguno con la administración de las oficinas salitreras, el oficio de libretera fue claramente reconocido por las administraciones, debido a su papel político como representante del obrero particular en el escritorio de las oficinas salitreras. Las faenas reconocidas dentro de industria, hayan sido de extracción, transporte, elaboración o servicios, estaban controladas por la administración de las oficinas salitreras, incluso labores como la de extracción del caliche que, si bien era a trato o destajo, donde trabajaban los particulares, existió sobre la base de una libreta de trabajo, do-

\footnotetext{
8 Existen estudios de arqueólogos sobre los lugares ocupados por las fraguas en desierto (Rees et al. 2006).
} 
cumento que -aunque irregular-generaba una relación contractual del obrero con la compañía.

Tanto los asentamientos humanos periféricos, los oficios o actividades realizados en plena pampa, los que transitan desde la transfrontera sin contrato con la compañía, aquellos que realizan quehaceres al interior de las viviendas del campamento, como lavanderas, yerbateras, parteras y cocineras, tienen algo en común: su heterología.

La cocina fue un margen interior heterológico, a pesar de su importancia en el proceso de reproducción de la mano de obra, donde la cocinera ocupó un lugar y un oficio no reconocidos y, por lo mismo, no alcanzó a tener una posición estratégica en la industria del salitre durante todo el ciclo de expansión. Sin embargo, esto cambiaría con la emergencia de un movimiento social de mujeres, quienes desde el espacio público descubren el carácter estratégico de este lugar y oficio femeninos.

Lo novedoso de la cocina es que su heterología no hace referencia a un extramuros, no está ubicada en plena pampa como los herreros que con su fragua se dedicaban a arreglar las herramientas, o los porquerizos que se dedicaban a la crianza de cerdos, animales tan apetecidos en la mesa pampina. Aunque estos criadores establecían una relación estrecha con los habitantes de las oficinas salitreras al intercambiar comida por lechones, siempre debían ubicarse a una distancia prudente que evitara la presencia de insectos en el campamento. La cocina en cambio está ubicada en las casas y, preferentemente, en las fondas o cantinas.

Cuando una familia llegaba a una oficina salitrera, sea a través de un enganche o por iniciativa propia, lo usual era que los varones de esa familia se presentaran en el escritorio de la administración para solicitar trabajo en alguna de las faenas, en cambio las mujeres debían hacerlo en otras labores. Homero Bascuñán describe con precisión el papel de las mujeres dentro del campamento salitrero:

"La mujer, en la Pampa, se las ingeniaba de distinta manera para ganarse el sustento. Muchas ayudaban a sus maridos con una 'cantina' (casa de pensión); las muchachas jóvenes lo hacían de 'libreteras' para aportar, también, alguna ayuda al mantenimiento del hogar; otras se instalaban en las esquinas del Campamento más cercanas a los sitios de trabajo a expender mote con huesillos y chicha de jora [...] Las noches de los sábados y domingos cambiaban este comercio por la fritanga de sopaipillas y empanadas en los aledaños del 'Biógrafo' o en las vecindades de 'La Fonda'. Por cierto que algunas mujeres tomaban lavados de los 'solteros"' (1976: 290).

La cocina, en tanto lugar concreto, fue un rincón de las casas del campamento con características notoriamente femeninas; en primer lugar el hecho que fueran construidas por ellas. La capacidad de las mujeres de construirlas como si fueran obras de artesanos, señala que se trata más de un oficio que un trabajo dentro del proceso industrial salitrero. En otras palabras se aproxima más a lo que Hannah Arendt define como "labor" (2009: 98). Lo anterior lo podemos comprobar con los testimonios de dos mujeres que vivieron en la pampa salitrera a comienzos del siglo veinte: Las señoras María Álvarez viuda de Tu-Kin y Luisa Campos:

"Sra. María Álvarez: Cocinas económicas de carbón, cuando no se tenía, las mismas mujeres las hacían, con unos 4 tarros llenos de tierra, se ponía la calamina encima, se hacía un hornillo para arriba con barro, que quedara a la altura de uno, se hacía una parrilla con fierros, ahi estaban las brasa, arriba pasaba la llama con un cañón por donde salía el humo para arriba. También cuando no se tenía se hacían también estirando las calaminas, después le hacían 2 hoyitos y otro para el cañón, si no tenía cañón se enrollaba una calamina se amarraba con alambre y listo el cañón, así se hacían, pero casi todas las casas de la oficina tenían cocina hecha más tres piezas grandecitas, comedor, dormitorio y cocina, en el patio el gallinero, una ramada donde iba la base".

"Sra. Luisa Campos: En la oficina Pan de Azúcar las casas eran de calamina y madera. Tenían dos piezas no más, y un patiecito así de cocina. La primera (pieza) era comedory la segunda dormitorio y nada más. Nosotros teníamos una cocina de fierro antigua. Se hacían también de barro. (En) la parte de abajo (de la cocina) se ponían cuatro latas (envases de parafina o manteca), después se llenaban de piedras y se armaba la cocina con ladrillos, y se ponía (encima) una plancha de fierro".

Como vemos, las mujeres hicieron las cocinas con sus propias manos, como si fueran artefactos. Las hicieron con barro y con todos los materiales que tuvieron disponibles: costra, piedras, fierros, planchas de zinc para el cañón o chimenea, etc. Era un artefacto, como si fuera una obra de artesano. 
Luis Miguel Isava, nos dice que "la palabra 'artefacto' nombra en realidad todo objeto que es producto de la aplicación de una técnica; es decir, 'artefacto' es todo aquello elaborado, producido por el ser humano" (2009: 440). En este caso, las cocinas pampinas fueron artefactos en contraposición a la máquina, que fue la expresión de la modernidad y que acaparó toda la atención de viajeros y fotógrafos que visitaron las salitreras (Bravo-González 1994). La cocina era, a pesar de su marginalidad, un mundo cultural y socialmente heterogéneo y, por lo mismo, con muchas discontinuidades. Allí se encontraron mujeres venidas desde comunidades muy diferentes, no sólo con otros saberes culinarios sino con lenguas diferentes, entre ellas el quechua y el aymara.

La cocina pampina no fue solamente un espacio heterológico, sino también un espacio heterotópico, porque allí -a pesar de su marginalidad dentro de la organización industrial- coincidieron diversos flujos de mercancías y saberes, desde los venidos de ultramar con toda la modernidad de la época, con aquellos otros, los traídos los por arrieros desde comunidades indígenas con sus tradiciones culinarias.

\section{* La pulpería y la cocina}

El aprovisionamiento de agua y alimentos en la fase de cateos fue determinante para el éxito de la búsqueda buenos mantos de caliche en el desierto de Atacama, el que estuvo a cargo de habilitadores o aviadores. Posteriormente, con la consolidación de las oficinas salitreras, el aprovisionamiento del agua y de los alimentos fue controlado por las Compañías a través de los administradores y de la pulpería. A partir de entonces se genera una tensa complementariedad entre la pulpería y la cocina.

La pulpería fue estratégica para las compañías salitreras y, por lo mismo, un centro de conflictos. Por ejemplo, la principal huelga pampina que registra la Historia del Salitre de diciembre de 1907, tuvo como principales peticiones: 1. Pago de los jornales y no fichas; 2. Pago de los jornales a razón de un cambio fijo de 18 peniques; 3 . Libertad de comercio en las oficinas en forma amplia y absoluta; 4 . Cierre general con rejas de fierro en todos los cachuchos y chulladores; 5 . La existencia de una balanza y vara fuera de las pulperías y tiendas para confrontar pesos y medidas;
6. Instalación de escuelas nocturnas; 7. Imposibilidad del administrador de aprovechar el caliche decomisado; 8. Desahucio de 15 días cuando el patrón ponga término al contrato. No hay demandas por alimentación ni por las habitaciones de los obreros, pero si está presente la pulpería.

La pulpería fue una importante fuente de ganancias para las compañías salitreras, como lo demuestran especialistas como los ingenieros Alejandro Bertrand, chileno, y E. Semper y E. Michels, alemanes. Cuando Bertrand hace el cálculo del precio de un quintal de salitre en cancha llega a un precio que se ubica entre 16,0 y 22,3 peniques, pero señala que debería descontarse 0,5 peniques por las ganancias de la pulpería (1892: 54); por su parte, Semper y Michels, establecen ese rango entre 14,4 y 36 peniques y el descuento por los beneficios recibidos en la pulpería sería de 1,2 peniques (1908: 94). Desde una óptica diferente, Antonio H. Ciar, concluyó que "después del salitre el negocio más lucrativo en la oficina es la pulpería. Aquello ya sobrepuja el límite de negocio, es más bien un descarado monopolio de explotación" (1897: 18), agrega cálculos sobre la base de 500 trabajadores, llegando a la conclusión que la pulpería puede alcanzar una utilidad de un $60 \%$.

Fue tan importante la pulpería en las utilidades de las salitreras que permitió una risible anécdota que recogió Marcelo Segall en su libro sobre la ficha-salario, relativa a un joven gerente en Londres de una firma salitrera, quien, revisando la contabilidad, sugirió el cierre de la "oficina" y fortalecer la "pulpería", porque la primera no producía utilidad y la segunda era un buen negocio (1964: 8).

La pulpería ocupó siempre en la industria del salitre una posición estratégica porque, por una parte, generaba utilidades para las compañías y, por otra, era un espacio de negociación/conflicto con los trabajadores, que entonces asumían la representación del reclamo de las mujeres.

El otro extremo de la pulpería era la cocina. La pulpería era el espacio público del abastecimiento y del conflicto, la cocina el espacio privado del consumo y de la contención. La pulpería era un espacio normado y vigilado.

La cocina pampina, entendida como un espacio laboral y de sociabilidad, no formó parte entre las labores formales de servicio en la cadena productiva de la economía salitrera durante todo el ciclo de expansión, a pesar de la in- 
negable importancia que ella tuvo en la reproducción de la mano de obra a través de la alimentación de los trabajadores, especialmente por el papel desempeñado por las fondas o cantinas, las que podían estar administradas por un hombre, "el fondero", las labores estuvieron a cargo de mujeres. La alimentación fue una actividad fundamental en esta sociedad como ha quedado registrado en la memoria de los pampinos (Sánchez 2013), pero no tuvo un reconocimiento dentro de la industria9. Las cantinas o fondas formaron parte del espacio público de la sociedad salitrera, siempre fueron un lugar identificable dentro de los campamentos, sin embargo, la cocina propiamente tal fue el rincón por antonomasia del espacio privado y del trabajo femenino. Desde allí, difícilmente, podría haber surgido la protesta social o la emancipación cultural.

Quedó en la memoria de los obreros de la minería del nitrato las "cuatro operaciones", que se referían a las cuatro comidas (desayuno, almuerzo, once y cena) que disfrutaban desde muy temprano en la mañana hasta la noche, ellas definían una parte del horario que tuvieron las mujeres que trabajaban en el oficio de cocinera, sea en las fondas/cantinas o en las casas familiares. El horario de trabajo de estas mujeres se iniciaba de madrugada con las compras en la pulpería y concluía con la limpieza del local y de la cocina. Como ejemplo de lo anterior, tenemos esta carta enviada el 21 de diciembre de 1933 por el periodista Atilano Oróstegui al Intendente de la Provincia de Antofagasta, después de hacer una visita a la pampa, denunciando las condiciones de vida en las oficinas salitreras, donde señala en una de sus partes:

"Pasaré por alto la situación en que se encuentra la gente que acude a las pulperías a hacer sus compras. Su señoría podrá imaginar fácilmente lo que debe sufrir esa gente condenada a permanecer de pie 3 y más horas en la mañana y otras tantas en la tarde. Ha habido mujeres que se han desmayado de debilidady con mayor razón las que han estado en cinta" (1933: 13).

La pulpería fue el espacio reconocido por la industria como parte fundamental de la economía del nitrato, por

9 La minería moderna considera a los casinos como parte fundamental en la logística de la empresa, donde incluso hay preocupación por la dieta balanceada y saludable de los trabajadores (Carrasco-Vega 2011: 85). lo mismo, donde se generaron los principales conflictos sociales relacionados con el abastecimiento de los productos básicos para los trabajadores, en especial de los alimentos. Posiblemente la huelga y masacre obrera más emblemática que tuvo origen en una pulpería fue en la oficina salitrera La Coruña (Vial 1988: 245) acontecida el 5 de junio del año $1925 .^{10}$

Solamente como referencia, incluimos un pequeño fragmento del testimonio de una mujer pampina, Señora Dorca Bugueño, quien vivió en La Coruña al momento del conflicto:

"(En La Coruña), ahí se juntó la gente, los oficineros cerraron portería, hubo un saqueo, yo he comido de saqueo, me dieron unos tarros de durazno, me llenaron mi canastita, era una muchachita, tenía sólo 14 años, me casé a los 13 años, porque los oficineros cerraron y se fueron (para que) vinieran las fuerza armadas, duró tres días la revuelta entre la gente que se juntaba ahí de San Pedro, de Berrenechea, esperando a que fueran unas autoridades de acá de Iquique a arreglar esta situación pero no fueron autoridades, fueron las fuerzas armadas y entraron disparando cuetes y la gente no tenía nada con qué pelear, la gente no podía pelear contra el ejército, los del ejército entraron a la oficina ahí empezaron a tomar a la gente, no mataron a muchos...

"De quien me acuerdo es del finado Barrera, lo mataron ahí mismo, mataron también a un jefe de pulpería, a un sereno, a un costrero...

"En el pique está la gente muerta, por ahí los tiraron, otros se arrancaban y al arrancarse los mataban..."

Sin embargo, la cocina fue el espacio silente, durante todo el ciclo de expansión del nitrato no existen referencias sobre su funcionalidad e importancia, probablemente quedaban tácitas tanto para las gerencias o administraciones de los campamentos salitreros como para las autoridades de la época, incluso para los dirigentes obreros. Hay información relevante sobre el costo de los productos y el papel de las pulperías, pero no es tarea fácil encontrar reglamentos internos en las oficinas salitreras que regularan el trabajo de las cantinas/fondas, menos aún

\footnotetext{
${ }^{10}$ La novela de Luis González Zenteno Los pampinos (1954) se refiere a esta masacre obrera.
} 
de las cocinas en general. Tampoco los informes de las Comisiones Consultivas $(1908,1913,1919)$ que visitaron el norte salitrero para evaluar la situación social en las salitreras, se refieren directamente al papel de la cocina o cocinerías, a pesar que abordan preferentemente temas como vivienda, prostitución, médico, correo, botica, higiene, cementerios, hospitales, salarios, trabajo, etc., donde las fondas son mencionadas por los juegos de azar (Salas Lavaqui 1908: 542). Posiblemente los pliegos de peticiones más completos presentados por los trabajadores -de tanto de la costa como de la pampa salitreras- al gobierno nacional, fueron los Memoriales Obreros de 1904, donde nada hace referencia directa al trabajo de las mujeres en general y de las cocineras en particular. En consecuencia, la respuesta de los salitreros, en los Memoriales de los Patrones, tampoco lo aborda (Reyes 1973).

En la industria salitrera incluso la labor a destajo o trato que los obreros de la pampa realizaban en las calicheras quedó reglamentada en las libretas de trabajo; por su parte las pulperías tenían un reglamento sobre pesos y medidas, y se prohibía la venta de alcohol. En cambio la alimentación de los obreros quedaba en el ámbito de su responsabilidad personal, a tal punto que algunos pampinos se abastecían en las calicheras ya sea por sus mujeres o por los niños loncheros. Las demandas obreras en las diversas huelgas realizadas en el período de expansión del ciclo salitrero no hacen referencia a las condiciones de vida de las mujeres cocineras.

Los saberes propios de la cocina en la pampa salitrera se transmitieron tácitamente en el sentido que Sergio Boisier le da a un tipo de conocimiento endógeno y local, contrapuesto al conocimiento codificado y exógeno (2005: 18). Por lo mismo, la memoria sobre la cocina quedó enmarcada en el espacio privado, resultando casi imposible encontrar referencias a ella en informes oficiales o relaciones de viajeros de época. Sin embargo, en testimonios y entrevistas de pampinos es uno de los temas que se recuerdan con más emoción e intimidad, porque formó parte esencial de la vida cotidiana. Como afirma Agnes Heller: "para la mayoría de los hombres la vida cotidiana es 'la' vida. Éste es el banco de pruebas para ver si el hombre, según las palabras de Goethe, es el hueso o la piel" (1970: 26).

El espacio de la cocina fue, esencialmente, un espacio de la vida cotidiana dentro del campamento minero salitre-

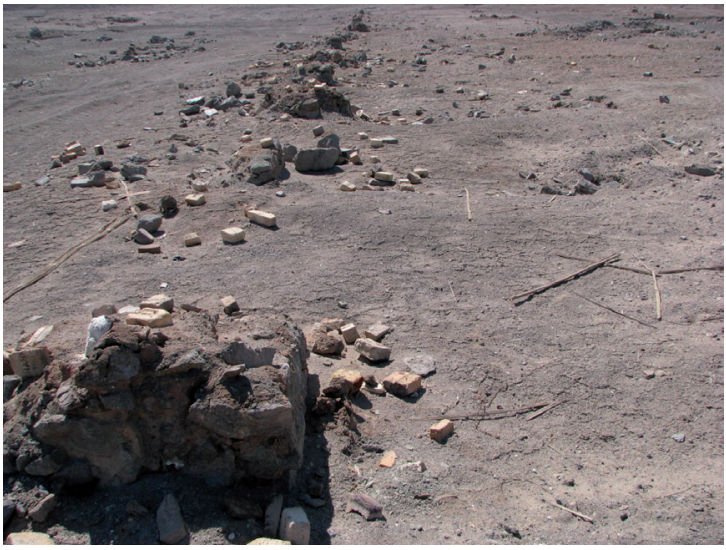

Figura 3. Cocina campamento San José.

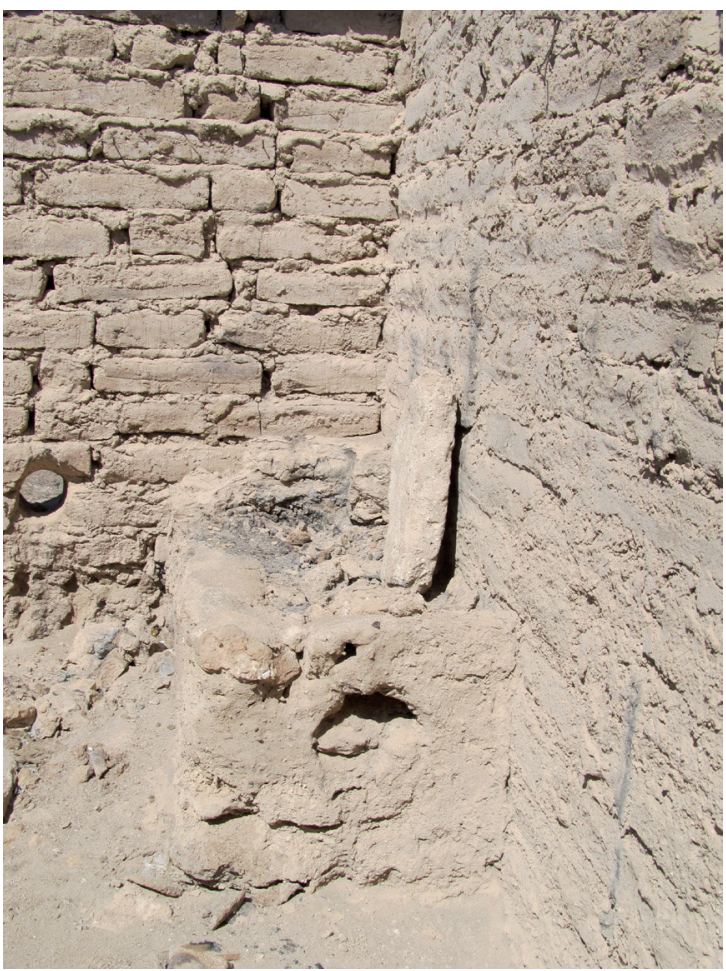

Figura 4. Cocina salitrera Santa Catalina.

ro. Siguiendo el pensamiento de Henri Lefebvre, Alicia Lindón plantea que el espacio de la vida cotidiana "es el de las prácticas de los actores, está cargado de significados y también es delimitado. En este espacio se incorpora la idea de 'límite' como una forma de recortar no sólo desplazamientos cotidianos de los actores, sino también ámbitos de significación asociados a la experiencia que 
los actores tienen de diferentes porciones del espacio" (2004: 42). El espacio de la cocina estaba delimitado, generalmente reducido a un rincón de las viviendas que, con el uso y el tiempo, se volvía un rincón oscuro y diferenciado (Figura 4).

Los campamentos salitreros, en general, debido a los materiales que se utilizaban en su construcción como las planchas de zinc o calaminas y la costra, comenzaban con el tiempo a deteriorarse, como lo registra un testigo de la época, Manuel Rodríguez Pérez, secretario de la Oficina del Trabajo en 1912:

"Las casas o galpones, cuyos techos y paredes son planchas de zinc, pedazos de costra de terreno o tablones unidos por lonas inmundas, seccionadas de dos en dos, constituyen las casas de las familias, cualquiera que sea el número de personas que las componen. No hay desagües ni servicios de aseo medianamente organizados, y contribuye a hacer más grave la situación la existencia de establos para los animales de carga en el interior de las manzanas en que están divididos los campamentos.

"Familias compuestas de 7 o más personas habitan en esas casas de dos piezas, una de las cuales destinada a comedory demás usos y la otra a dormitorio de los padres y de todos los hijos, ya sea de corta edad o adultos, hombres y mujeres. Los trabajadores solteros comen en las fondas o "cantinas" y duermen de a dos o tres en cada pieza de las casas reservadas para hombres solos" (1913: 174).

Por ello, Frías Collao se pregunta: “icómo extrañarse, entonces, de que el obrero de la pampa salitrera, obligado a vivir en esos tugurios infectos y reñidos con toda comodidad y aseo, se vea invenciblemente arrastrado hacia la crápula y el alcohol?" (1911: 19). Nosotros podríamos preguntarnos si esa condición de alienación explica también el que nunca -durante el ciclo de expansión del salitre- haya surgido demanda social o emancipación cultural alguna desde un espacio marginalizado y arrinconado como la cocina. Sin embargo, resulta novedoso que desaparecida la pulpería y la administración cuando la industria salitrera debió paralizar durante las grandes crisis como las de 1919 y 1930, la demanda por la sobrevivencia básica de los obreros y sus familias no fue hacia los patrones sino hacia el Estado, como lo señala Damir Galaz respecto de la "olla del pobre" en Tocopilla, "para dimensionar la mentalidad de la época, la cual básicamente se orientaba a concebir al Estado como un ente que debería socorrer a la comunidad en todo momento y llegar hasta los ínfimos detalles, como el de dar pan en el almuerzo" (2013: 140). No todos los obreros escogieron ese camino del paternalismo, muchos partieron hacia sus comunidades de origen. Del mismo modo, durante medio siglo que aproximadamente duró el ciclo de expansión del salitre, hubo miles de obreros, hombres y mujeres, que se movilizaron y levantaron pliegos de peticiones en una larga historia social (Grez 2000; Pinto 2007).

Las mujeres en general no estuvieron al margen de los movimientos sociales salitreros. Se organizaron en paralelo con los hombres -según sus oficios- en mutuales y sociedades de socorros mutuos, desde fines de la década de 1880, donde se puede destacar, por ejemplo, a Adela Zamorano, presidenta de la Sociedad de Obreras (Pinto 1998: 185). En la pampa se también se formaron organizaciones de mujeres, siendo los centros Belén de Sárraga los más conocidos, donde la figura de Teresa Flores, entre otras, tuvo un protagonismo. También en el periodismo obrero hubo mujeres, como Delfina C. de Díaz y Herminia U. de Orellana, en el periódico El Pueblo, dirigido por Osvaldo López. Empero, no fue el caso de determinados oficios, como las sirvientas o las cocineras. Una pista posible del por qué quedaron fuera, puede ser la distinción entre trabajo y labor, entendiendo al primero como productivo y la segunda como improductiva, por lo tanto, las cocineras (como las sirvientas) no eran en rigor obreras. Según Arozamena, "la heterología era, siempre para Bataille, la ciencia de lo irrecuperable, cuyo objeto no sería otro que 'lo improductivo' por excelencia: los desechos, los excrementos, la inmundicia. En síntesis, la existencia 'otra' expulsada de todas las normas: la locura, el delirio, etc." (2014: 56). La cocina quedó oculta por su supuesta improductividad dentro del proceso industrial, donde lo productivo era lo funcional a la elaboración del nitrato de soda.

Todo este proceso industrial: cateo - extracción transporte -molienda - lixiviación - transporte - exportación, resulta homogéneo, sin interrupciones ni discontinuidades. Arozamena, interpretando a Bataille, señala que éste "distinguía dos polos estructurales: por un lado lo homogéneo, o ámbito social útil y productivo, y por el otro lo heterogéneo, lugar de irrupción de lo que 
es imposible de simbolizar. Así, ayudándose de este concepto, iba a especificar la idea de "parte maldita" (2014: 56). Por ello, tiene razón Hannah Arendt cuando afirma que "el auténtico desarrollo histórico que sacó a la labor de lo oculto y la llevó a la esfera pública, donde pudo ser organizada y dividida, constituyó un poderoso argumento en desarrollo de estas teorías (que consideraban a toda labor como trabajo)" (2009: 103).

¿Por qué las mujeres debieron asumir esa labor en la cocina en la pampa salitrera?, la respuesta puede ser: porque la demanda para las faenas dentro del proceso industrial fue de mano de obra masculina. También otra respuesta está relacionada al género, porque como bien indica Michelle Perrot: "las mujeres siempre trabajaron. Un trabajo del orden de lo doméstico, de la reproducción; un trabajo no valorizado, no remunerado" (2009: 137). Incluso esta autora afirma que, a pesar de su importancia, ha sido un trabajo "invisible" para la sociedad. Luce Giard acota la importancia que para Europa ha tenido: "la cuestión del papel (iprivilegiado?) de las mujeres en la preparación de alimentos que se comen en la casa. No es que yo crea en una naturaleza femenina, inmanente y estable, que consagraría definitivamente a las mujeres a las labores del hogar, que les daría el monopolio de la cocina y la organización interior" (2010: 153). Precisamente ese monopolio es el que habría permitido, siempre y cuando el sujeto no se enajenara en dicho espacio heterológico, un papel político y estratégico a las mujeres de la pampa que desarrollaban esa labor/oficio de cocineras.

Efectivamente, aunque tuvo que pasar todo el ciclo de expansión del nitrato, no fueron los hombres sino las mujeres las que comprendieron que desde ese conocimiento tácito que emerge de la cotidianidad era posible transformar a ese espacio heterológico, conocido como "cocina pampina", en una posición política estratégica en 1941 cuando se inició la "huelga de las cocinas apagadas".

\section{* La cocina y la posición estratégica}

El tipo de campamento que predominó durante del ciclo de expansión del salitre fue el que podríamos calificar de Shanks en contraposición al Guggenheim (González Pizarro 2003). En estos campamentos había una iden- tidad inclusiva, donde todos formaban parte: aquellos con contrato, los obreros particulares y quienes trabajaban en oficios de servicios, como los oficios o labores que realizaban mujeres. Tácitamente la administración reconocía y aceptaba a todos los oficios y labores que podrían reconocerse como parte de la vida cotidiana del campamento, aunque estuvieran lejos de sus muros, como fue el caso de los criadores de cerdos o los "herreros-pampa". Podrían definirse como oficios "del campamento", porque formaban parte del mismo locus residencial, a diferencia de los mercachifles que las administraciones consideraban externos y competitivos de la pulpería, por tanto, a veces, eran violentamente expulsados fuera de sus muros.

La vulnerabilidad y precariedad de ciertos oficios de mujeres que se ejercían dentro del campamento como aquellos asociados a las cocinas, al parto, a la medicina tradicional, entre otros, no lo eran solamente por la inexistencia de un contrato o por la razón de género. Hubo otros oficios como fue el caso de las libreteras que no tenían contrato con la administración y lo ejercían mujeres, pero que eran reconocidos y tuvieron alto prestigio entre los obreros, posiblemente ellas se podían considerar a sí mismas como obreras. La razón de ese prestigio tuvo relación con la "posición estratégica" que los distintos oficios tuvieron frente a la administración de las salitreras.

La posición social de la cocinera dentro de la estructura organizacional de esta industria no fue reconocida como estratégica, a pesar que de ella dependía la reposición diaria de la energía laboral de los obreros, lo que se debió más a una percepción de precariedad y vulnerabilidad que a condiciones objetivas de ser un oficio irrelevante. Dicha percepción pudo originarse a partir de la condición social de las mujeres que ejercieron este oficio al inicio del ciclo del salitre que, sostenemos, eran indígenas o mestizas. Posiblemente, algunas mujeres pudieron haber desempeñado, en el período de paradas, cuando Tarapacá era peruano, el oficio de cocineras siguiendo a sus maridos o hijos, y que fueron conocidas como vianderas o rabonas. El historiador peruano Juan José Rodríguez Díaz las define de este modo: "las llamadas rabonas no serían otra cosa que las mujeres que optan por cumplir su deber con su marido y convierten su hogar en un lugar movible" (2009: 108). 
¿Por qué la cocina, como espacio económico y social, no fue una posición estratégica dentro de la industria del nitrato durante el ciclo de expansión? El historiador norteamericano John Womack jr., descubre que existen posiciones estratégicas en las relaciones laborales, que van "más allá de las relaciones de producción o de las relaciones sociales de trabajo" (2007: 50). La idea central está basada en la existencia de posiciones, dentro de la estructura de producción, más estratégicas que otras y que no necesariamente tienen que ver con la mayor calificación de quienes las ocupan, sino porque ellas son clave para el funcionamiento general de la industria y, por lo tanto, tendrían una ventaja en su capacidad negociadora. Womack apunta, en otra parte de su estudio, que los "grupos no eran estratégicos por su posición o algún otro atributo, sino por su conducta", y dicha conducta estaría dada por el "carácter esencial de su función o grado de indispensabilidad, facilidad de reemplazo, carácter crítico de su habilidad, carácter esencial de su ubicación..." (2007: 90). En el caso de las cocinas pampinas, como espacio estratégico, precisamente no tiene que ver con la calificación laboral de quienes ejercieron el oficio de cocineras, sino de su ubicación dentro del proceso general de producción industrial del nitrato de soda, en la dificultad de su reemplazo y el carácter crítico de su habilidad. El trabajador de la pampa no aceptaría cualquier comida en reemplazo de sus "cuatro operaciones". ${ }^{11}$ Las mujeres, por lo mismo, se esmeraron en responder a esa demanda, trasladando el conflicto hacia la pulpería como el espacio de abastecimiento de los insumos, pero nunca pensaron -hasta $19411^{12}$ en ocupar a la cocina como el espacio del conflicto, posiblemente porque a la vez era el espacio de la intimidad y de la cotidianidad. Más adelante revisaremos este quiebre o discontinuidad del cambio de un espacio invisibilizado, marginalizado, heterológico, por otro en movimiento, en crisis, heterotópico.

Autores más recientes que han abordado la cocina como espacio cotidiano, plantean que

${ }^{11}$ Se refiere a su alimentación habitual compuesta por desayuno, almuerzo, once y comida, todas similares en cantidad y tipos de comidas.

12 En su discurso "Yo Acuso", Pablo Neruda hace referencia a esta huelga de "las cocinas apagadas" en 1941 (Olivares 2004: 561).
"En principio, las cocinas de casa son -ya lo decíamos ante- espacios de poder de las mujeres, sin que eso signifique que ellas así lo reconozcan; es, en efecto, un espacio de poder, pero utilizado como un espacio de amor, la que guisa tiene en su mente y en sus emociones la presencia de sus comensales, pues sabe que está creando vida y salud. No intenta mostrar su poderío, sino sus saberes para cuidar a los demás, y únicamente espera una recompensa subjetiva y a la vez muy concreta: que los demás saboreen sus platillos, cualesquiera que éstos sean" (Márquez y Navarro 2011: 96).

Esta mirada moderna sólo coincide con nuestro análisis en el aspecto que la cocina es un espacio de poder de las mujeres pero no reconocido, incluso por ellas mismas. Aunque en la pampa salitrera podríamos reconocer una cultura culinaria (Sánchez 2013), ella no fue la razón de esa alienación de las cocineras.

Las cocineras pampinas tenían mayor cercanía con otras mujeres de la pampa como lavanderas, parteras y yerbateras, mujeres indígenas o mestizas, por su alteridad respecto de la población masculina y especialmente de la administración. Como vemos estas otras mujeres y sus oficios no tenían ese carácter estratégico respecto de quienes dependía la alimentación diaria de los trabajadores. Sin embargo, mientras esas mujeres no tomaran conciencia de la importancia estratégica de la cocina, ésta seguiría estando en un margen de la economía y de la sociedad pampinas.

\section{* La huelga de las cocinas apagadas}

Existen algunos antecedentes periodísticos y en la web sobre movimientos de mujeres, tanto en el salitre como en el carbón, donde supuestamente se utilizaron las cocinas como herramientas de lucha social. Incluso varios autores mencionan a las "cocinas apagadas" hacia 1918, lo que resulta coherente con el movimiento de mujeres que se inicia después de las dos visitas realizadas por la librepensadora española Belén de Sárraga al norte salitrero -en 1913 y 1915 - después de las cuales se organizaron los centros femeninos anticlericales que llevaron su nombre. También la creación en 1919 del Partido Femenino de Chile, el primero en su clase (Kirkwood 1987: 102). Lamentablemente, por razones de espacio no podemos hacer un recuento de esos trabajos sobre "las cocinas 
apagadas" de 1918, sino solamente señalar que no hemos podido encontrar referencias en archivos ni en periódicos de época sobre esos movimientos sociales de mujeres. Lo anterior explicaría, parcialmente, la ausencia de referencias a las "cocinas apagadas" en la historiografía nacional que aborda la lucha social de las mujeres en la pampa salitrera y en otros espacios mineros. Solamente algunos autores hacen referencia a las luchas sociales de la década de 1940 sin llamarle necesariamente "cocinas apagadas", especialmente las huelgas de 1946 y 1947, como es el caso de Crisóstomo Pizarro (1986: 125 ss.). También la historiadora antofagastina María Ahumada se refiere a las "ollas vacías" (2003: 148), debido a la escasez de alimentos durante esos años 1946-1947, basado en información de prensa aparecida en El Mercurio de Antofagasta.

Fue la presencia del MEMCH (Movimiento Pro-Emancipación de las Mujeres de Chile) en la pampa salitrera el que generó la huelga de las cocinas apagadas en 1941, que relatamos más adelante. Este movimiento estaba compuesto por mujeres militantes y, por lo mismo, con formación política. Fue fundado en Santiago el año 1935, por lo que no es extraño que años después estuviera en las salitreras. Olga Poblete, una de sus fundadoras, relata el origen de este movimiento pero no se refiere a esta huelga, solamente aborda la relegación a Pisagua de sus militantes durante el gobierno de Gabriel González Videla (1983: 161-168).

Aunque ya había concluido el ciclo de expansión del nitrato chileno, todavía quedaban en todo el desierto de Atacama, desde Pisagua hasta Taltal, oficinas salitreras trabajando, muchas de ellas todavía bajo el sistema de lixiviación Shanks. Muchos problemas laborales que se vivieron en el período de auge siguieron existiendo en la pampa a pesar de las leyes sociales imperantes desde la llegada de Arturo Alessandri al gobierno central, por ello, no dejaron de presentarse huelgas en diferentes cantones salitreros.

El sábado 5 de julio de 1941, el periódico El Tarapacá registra uno de esos movimientos huelguísticos, que no tendría nada de extraordinario si no fuera que, según este periódico "[... 930 obreros de Santa Laura y Cala Cala declararon ayer un paro ilegal para lo cual usaron como instrumento a las mujeres de ambos campamentos. Dieron como pretextos el alza de veinte a cuarenta centavos en el precio del kilo de carbón, que acaba de establecer la Compañía Salitrera de Tarapacá y Antofagasta. El señor intendente tomará drásticas medidas, en especial con los cabecillas..." (p. 3).

En realidad, desde la perspectiva de las mujeres, este movimiento fue una iniciativa de ellas, quienes, al tomar conciencia de la importancia de las cocinas como engranaje clave en el proceso industrial, decidieron apagarlas, obligando así a los trabajadores a paralizar las faenas.

El periódico insiste en que las mujeres sirvieron "de instrumento" a los huelguistas, lo que no queda bien establecido, porque también califica a los dirigentes de carecer de hombría, a saber:

"Como los dirigentes comunistas sindicales de Santa Laura y Cala Cala saben bien que el paro con el pretexto aludido es ilegal, recurrieron, para justificarlo, a un procedimiento que demuestra su falta de hombría. En efecto, instigadas por ellos, -y en especial por el actual y el expresidente, José Cortés y Jesús Godoy, respectivamente, según se pudo establecer más tarde-, las mujeres dejaron de comprar carbón cuando se fijó el nuevo precio y de esta manera ayer no tenían combustible y los obreros salieron a trabajar sin haber tomado desayuno. Pero, de acuerdo con el plan debidamente trazado por los dirigentes sindicales, las mujeres de Santa Laura se colocaron en la vía férrea en los instantes en que iban a pasar uno de los trenes en que los obreros eran trasladados a las calicheras para iniciar su labor matinal. Entonces esos obreros, las mujeres y algunos trabajadores se reagruparon y regresaron al Campamento para dar cuenta de que no trabajaban mientras no se dejara sin efecto el alza de veinte centavos en el kilo de carbón".

En Antofagasta La Hora del Norte, del mismo día sábado 5 de julio, señala en una parte de su crónica que:

"El Ministro (del Interior) impartió al Intendente de Tarapacá don Florencio Martínez a fin de que lograra un entendimiento con los huelguistas para evitar el paro anunciado, pero en caso de que las gestiones tuviesen el éxito deseado, se hiciese respetar por todos los medios que tiene a su alcance de libertad y trabajo..." (p. 1).

También La Gaceta deArica, Año II, N 374, del sábado 5 de julio de 1941, señalaba en su primera página:

"Santiago, 5.- El Intendente de Tarapacá ha comunicado telegráficamente al Ministro del Interior, que 950 obreros de 2 oficinas 
salitreras de esa provincia, paralizaron sus faenas como protesta por haberse alzado en $\$ 0.10$ el kilo de carbón. Momentos más tarde reanudaron sus labores, acordando fijar un plazo hasta el domingo a fin de que se reconsidere esta alza, o en caso contrario declararían la huelga.

El Ministro señor Olavarría impartió instrucciones al Intendente para que evite esa huelga, prometiendo buscar una solución...."

Todo apuntaba hacia el Movimiento Pro-Emancipación de las Mujeres de Chile (MEMCH), organización política femenina que estaba en plena actividad en la pampa salitrera. Según la señora Lucrecia Pallacán:

"[...] vinieron los tiempos malos también, vinieron cuando ya estábamos en la oficina Iris, ahí para las huelgas que justamente ya teníamos como catorce o quince años, teníamos que pertenecer todas, pertenecían las mamás al grupo $M E M C H$, primero eran las dueñas de casa, después fueron las memchistas, se reunía la huelga de las señoras, era cuando íbamos a la pulpería. Si hoy día tocaba que nos vendían la leche, la mantequilla y medio pan de jamón y si no habian esas cosas era huelga, entonces no se cocinaba a los maridos, se reunían todas las señoras puerta por puerta porque no había qué cocinar debido a que faltaban artículos de primera necesidad en la pulpería, cuando ya estaban todos de acuerdo que a las diez de la mañana, porque a las once bajaban los particulares, porque ya tenían que estar afuera, pero habian señoras que tenían niños y ellas cocinaban y mi madrina era presidenta de las memchistas, Doña Juana Zapata, entonces como nosotros teníamos que hacer lo que ella nos mandaba, teníamos que subirnos arriba del techo y de acá nos pasaban los baldes con agua para que nosotros apagáramos las cocinas, teníamos que apagarle la cocina a la gente".

Antes de 1941 hemos podido registrar un movimiento de protesta, en el Archivo de Intendencia de Tarapacá, respecto de los artículos que se repartían a los cesantes, como también años después de acontecida esta huelga de las cocinas apagadas. Precisamente, el 18 de noviembre en el libro de Carabineros señala a la oficina Iris, donde se encontraba la señora Lucrecia Pallacán, junto a la oficina Brac, como "focos de este movimiento". ${ }^{13}$

Observemos el emocionante testimonio de la señora Pallacán en la oficina Iris ese año 1941:

${ }^{13}$ ITAR-1774, libro Carabineros, fichas números 43 y 48.
"[... tuvimos que pasar mucha hambruna porque hubo un tiempo que en el sindicato para la última huelga que hizo en la mina de los Urruticoechea no se podía comer ya, porque usted sabe que en todas partes pasa lo mismo entonces hacían una bodega, que estaba llena de mercadería, pero siempre la olla común era lo mismo, los porotos lo que se dio no más y a veces los hombres los botaban (mala calidad), entonces al casado les daban ración y ahí se dejaban azúcar, té, así que teníamos que hacer nosotros, nos juntábamos un grupo de chiquillos les íbamos a decir, pero no con mala intención, una se quedaba en la noche que cerraran todo, tenían que meterse debajo de una banca, para poderle robar a los mismos dirigentes y repartirnos las cosas, y después teníamos que salir por la ventana porque nos apagaban la luz a las ocho, o sea a las siete de la tarde no teníamos luz eléctrica, después mucho más antes que esto, nosotros nos vinimos de la oficina, estábamos en Don Guillermo, hubo un tiempo que mis padrinos se enfermaron entonces yo tuve que irme donde mi papá, mis verdaderos padres que estaban en (el campamento) Don Guillermo y hubo un paro y ese paro era venirse a pie para acá (Iquique), y llegamos aquí".

El 22 de noviembre de 1941, en la Oficina Brac, las mujeres se negaron hacer las compras en la pulpería, según en el Informe de Carabineros: "alegando que era muy restringida la cantidad de víveres que se les vendía, lo que no alcanzaba para hacerles la comida a sus pensionados o maridos". Sin embargo, se señala que el movimiento fue prontamente disuelto por las propias mujeres cuando éstas se percatan de la llegada de un piquete de carabineros. ${ }^{14}$ Siguiendo a este Informe de Carabineros, el movimiento tiene como cabecillas a las dirigentes del MEMCH Julia Vásquez, de la Oficina Alianza, Elva Castro Molina, Olga Morales Contreras y María Videla Olivares, de la Oficina Brac, y "respaldadas por los Sindicatos de esas Oficinas, especialmente por los comunistas Manuel Pinto o Rigoberto Pinto y Miguel López Rojas, llegados hace más o menos tres meses procedentes de la Oficina María Elena". ${ }^{15}$

La huelga de julio de 1941 se resolvió cuando, según $E l$ Tarapacá de Iquique del domingo 6 de julio:

"A pedido del gobierno la Compañía Salitrera de Tarapacá y Antofagasta dejó sin efecto el alza en el precio del carbón. La

\footnotetext{
${ }^{14}$ ITAR - 1774, Libro Carabineros, Ficha 43, 1941, sin fojas.

15 Ibídem.
} 
medida fue adoptada en la mañana de anteayer, mientras se efectuaba el paro ilegal de los obreros de Santa Laura y Cala Cala y sin que ni el Gobierno ni la Gerencia en Santiago de la Compañía, tuvieran conocimiento en esos instantes de tan insolente actitud..." (p. 3).

Por su parte, La Hora del Norte de Antofagasta, Año I, no 133, del miércoles 9 de julio de ese año, en su página 1, afirmaba:

"Santiago, 8.- En conversación telefónica sostenida entre el Ministro del Interior y el Intendente de Tarapacá, se consideró la situación producida en la provincia de Tarapacá en relación al alza del precio del carbón.

Sobre el particular se ha informado que los obreros habían acordado paralizar sus labores debido a esta situación. Bajo la promesa que este problema sería solucionado, el Intendente logró conseguir que el paro no se hiciera efectivo...".

La señora Adelina Lara, quien participó del MEMCH en la oficina Mapocho, nos relata el sentido del movimiento para la huelga de las cocinas apagadas:

"Bueno después hubo racionamiento, de primera no había. Después nos daban una tarjeta para la ración de azúcar. Nos daban de todo con la tarjeta. No nos faltaba. Donde éramos familia nos daban más cosas. Empezando de la carne, del carbón en esos años, se cocinaba con carbón de piedra. Al menos a mí no me faltaba porque éramos tres y nos daban tres raciones, empezando de la carne. Era buena la oficina.

[...] a veces se guardaban la mercadería. Nosotros llamábamos a la directiva del MEMCH, nos juntábamos ahí, entonces nombraban comisiones para ir a la pulpería a meterse para adentro, a las bodegas y a veces encontrábamos mercadería ahí, así es que hacíamos venderla al público. Si asi éramos nosotros.

[...] También, cuando no, nos largábamos a las máquinas a sacar a los compañeros del trabajo, cuando nos metíamos, cualquier problema que tuviéramos. Al menos yo lo digo porque yo era la que se subía a las máquinas llamando a la gente a reunirse en el Sindicato para hacer los reclamos contra los administradores.
[...] Muchos hacían caso porque en esos años, como le digo éramos todos únicos en esos años y nosotras como cocineras que éramos también. Nos faltaba aloo, era justo que reclamáramos porque era para ellos mismos el beneficio, para conseguir los artículos porque si no tendríamos que haber ido a Huara a pagar las ganas por la mercadería. Así que por eso nosotros nos largábamos..."

La "huelga de las cocinas apagadas" de 1941, no tenemos la certeza que haya sido la primera de su tipo, pero tampoco podemos afirmar con suficientes antecedentes de archivos que hubiera otra antes, sea en 1918 o en otro año; pero sí sabemos que no fue la última en esa década. Crisóstomo Pizarro aborda las movilizaciones de 1946, a las que define como "el paro general de 1946", pero no como "cocinas apagadas". Señala textual:

"El movimiento fue iniciado por los trabajadores de la Compañía Salitrera de Tarapacá y Antofagasta (COSATAN) en las oficinas Humberstone y Mapocho. Posteriormente se plegaron en solidaridad los trabajadores de otras oficinas, llegando a un total de unos 10.000 obreros comprometidos en el movimiento. El motivo aducido por los trabajadores para realizar este paro fue el alza de los artículos de pulpería, que violaba un acuerdo anterior con el sindicato. Como según la COSATAN no había existido tal violación, los trabajadores pidieron la intervención del Gobierno. En el curso de los días siguientes nuevos objetivos se agregaron a la huelga, alegándose por la violación del escalafón de los obreros de maestranza, pago de los días no trabajados en un anterior movimiento huelguístico, pocas condiciones de higiene y seguridad. Empero, el centro de las demandas continuó siendo el precio de los artículos de pulpería" (1986:126).

La acción del gobierno de Gabriel González Videla significó la persecución de las dirigentes del MEMCH (Poblete 1983: 161) y, por añadidura, el término de este tipo de movimientos sociales. Sin embargo, en las décadas siguientes surgirían las ollas comunes, las marchas desde las oficinas salitreras hacia los puertos y las banderas negras.

Agradecimientos Proyecto Fondecyt No 1130517. 


\section{* Referencias citadas}

AHUMADA, M. 2003. Antofagasta, ciudad con historia. El Mercurio de Antofagasta, Antofagasta.

ALCANTUD, V. 2005. Bajo el materialismo de Georges Bataille. Laberinto 19(3): 74-84.

ARENDT, H. 2009. La condición humana. Editorial Paidós, Buenos Aires.

AROZAMENA. A. 2014. Escalaborne. Jaculatorias místicas a favor (y en contra) del Arte y la Literatura. EIKASIA 55: 49-72.

BASCUÑÁN, H. 1976. De los días perdidos. Editorial Nascimento, Santiago de Chile.

BERMÚDEZ, O. 1963. Historia del Salitre. Desde sus orígenes hasta la Guerra del Pacífico. Ediciones de la Universidad de Chile, Santiago de Chile.

BERTRAND, A. 1910. La crisis salitrera. Louis Michaud Editor, París. 1892. Memoria acerca de la condición actual de la propiedad salitrera en Chile y exposición relativa al mejor aprovechamiento de los salitrales del Estado. Imprenta Nacional, Santiago de Chile.

BILLINGHURST, G. 1889. Los capitales salitreros de Tarapacá. Imprenta de El Progreso, Santiago de Chile.

BOUDAT, L. 1889. Salitreras de Tarapacá. L. Boudat y C Editores, Iquique.

BRAVO, P. y S. GONZÁLEZ. 1994. Iquique y la pampa. Relaciones de corsarios, viajeros e investigadores (1500-1930). Ediciones Camanchaca, Iquique.

CARRASCO, C. y P. VEGA. 2011. Una aproximación a las condiciones de trabajo en la gran minería de altura. Dirección del Trabajo, Cuaderno de Investigación 40, Santiago de Chile.

CIAR, A. H. 1897. El defensor del pampino. Imprenta y Encuadernación Sudamericana, Iquique.

CROZIER, R. 1997. El salitre hasta la Guerra del Pacífico. Una revisión. Historia 30: 53-126.

DÍAZ, A., L. GALDAMES y R. RUZ. 2009. Población indígena mestiza y negra de Arica y Tarapacá. Documentos republicanos (1827-1841). Ediciones Universidad de Tarapacá, Arica.

FOUCAULT, M. 2010. El cuerpo utópico. Las heterotopías. Ediciones Nueva Visión, Buenos Aires.
FRÍAS COLLAO, E. 1911. Las habitaciones obreras en Chile y en el extranjero. Oficina del Trabajo, Imprenta Santiago, Santiago de Chile.

GALAZ-MANDAKOVIC, D. 2013. Migración y biopolitica. Dos escenas del siglo XX tocopillano. Retruécanos Ediciones, Tocopilla.

GONZÁLEZ, S. 2013. La sociedad del salitre. Protagonistas, migraciones, cultura urbana y espacios públicos. RIL Editores, Santiago de Chile.

2006. Pampa escrita. Cartas y fragmentos del desierto salitrero. DIBAM, Santiago de Chile.

GONZÁLEZ, S. y P. ARTAZA. 2013. El concepto de "cantón salitrero" y su funcionalidad social, territorial y administrativa: los casos de Zapiga, Lagunas y el Toco. En La sociedad del salitre, S. González (Comp.), pp. 325-366. RIL-INTE Editores, Santiago de Chile.

GONZÁLEZ PIZARRO, J. A. 2003. La pampa salitrera en Antofagasta. Auge y ocaso de una era histórica. La vida cotidiana durante los ciclos Shanks y Guggenheim en el desierto de Atacama. Corporación Pro Antofagasta, Imprenta Ercilla, Antofagasta.

GONZÁLEZ ZENTENO, L. 1956. Los pampinos. Editorial Prensa Latinoamericana, Santiago de Chile.

GREZ, S. 2000. Transición en las formas de lucha: motines peonales y huelgas obreras en Chile (1891-1907). Historia 33: 141-225.

HERNÁNDEZ, R. 1930. El salitre. Resumen histórico desde su descubrimiento y explotación. Imprenta Fisher Hnos., Valparaíso.

KIRKWOOD, J. 1987. Feminarios. Ediciones Documentas, Santiago de Chile.

LABARCA, R. 2009. La comida en la pampa durante el auge salitrero en Chile: una visión desde la zooarqueología histórica. Revista Española de Antropología Americana 39(2): 101-114.

LINDÓN, A. 2004. Las huellas de Lefebvre sobre la vida cotidiana. Revista Veredas 8:39-60.

LUCE, G. 2010. Hacer de comer. En La invención de lo cotidiano 2. Habitar, cocinar, M. de Certeau, L. Giard y P. Mayol, pp. 151-265. Universidad Iberoamericana, Instituto Tecnológico y de Estudios Superiores de Occidente, México.

MACUER LLAÑA, H. 1930. Manual práctico de los trabajos en la Pampa Salitrera. Talls. Gráficos Salesianos, Valparaíso.

MÁRQUEZ, M. yA. NAVARRO. 2011. Espacios cotidianos y subjetividad: el caso de la cocina. Educação e Fronteiras on-line 1(2): 89-97. 
OLIVARES, E. 2004. Pablo Neruda: Los caminos de América. LOM ediciones, Santiago de Chile.

PÁEZ, R. 200o. Porotos y “raspa buches": alimentación del peonaje minero en el norte chico (1814-1910). Revista de Historia Social y de las Mentalidades 1(6): 160-198.

PERROT, M. 2009. Mi historia de las mujeres. Editorial FCE, Buenos Aires.

PINTO, J. 2007. Desgarros y utopías en la pampa salitrera. La consolidación de la identidad obrera en tiempos de la cuestión social (18901923). LOM ediciones, Santiago de Chile.

1998. Trabajos y rebeldías en la pampa salitrera. Editorial Universidad de Santiago, Santiago.

PIZARRO, C. 1986. La huelga obrera en Chile, 1890-1970. Ediciones SUR, Santiago de Chile.

POBLETE, O. 1983. El MEMCH, un capítulo del militantismo chileno. Revista Araucaria 24: 160-168.

REBOLLEDO, L. 2009. Las mujeres de la Pampa: ¿Invisibles o ausentes en la masacre de Santa María de Iquique? En $A$ cien años de la masacre de Santa María de Iquique, P. Artaza, S. González y S. Jiles (Eds.), pp. 400-411. LOM ediciones, Santiago de Chile.

REES, CH., C. SILVA y F. VILCHES. 2006. Viviendo y trabajando en la pampa: fraguas, cocinas, comedores y campamentos en los extramuros de las oficinas salitreras del cantón El Toco, María Elena, región de Antofagasta. Informe Final Plan de medidas de mitigación y compensación arqueológica Proyecto Cambio Tecnológico María Elena. SOQUIMICH.

RODRÍGUEZ, M. 1913. El trabajo i la vida obrera en Tarapacá. Imprenta "Santiago", Santiago de Chile.

RODRÍGUEZ J. C. y P. A. MIRANDA. 2008. Tiempo industrial y tiempos sociales en María Elena, la última ciudad del salitre. Chungara 1: 81-97.
RODRÍGUEZ, J. J. 2009. El bello sexo en guerra: cultura política y género durante la Guerra del Pacífico. Revista ILLAPA 5: 83-120.

RUSSELL, W. 1890 . A visit to Chile and the nitrate fields of Tarapacá. J.S. Virtue \& Co., London.

RUZ, R., A. DÍAZ y L. GALDAMES. 2008. Población andina de la provincias de Arica y Tarapacá. Ediciones Universidad de Tarapacá, Arica.

SÁNCHEZ. R. 2013. Las clases, las comidas y los banquetes en la sociedad salitrera. En La sociedad del salitre, S. González (Comp.), pp. 305-324. RIL-INTE Editores, Santiago de Chile.

SEGALL, M. 1964. Biografía social de la ficha salario. Ediciones de la Revista Mapocho, Tomo II, $\mathrm{n}^{\circ}$ 2, Santiago de Chile.

SEMPER E. y E. MICHELS. 1908. La industria del salitre en Chile. Imprenta Barcelona, Santiago de Chile.

VIAL, G. 1988. Historia de Chile (1891-1973). Editorial Zig-Zag. Volumen III, Santiago de Chile.

VILCHES, F., CH. REES y C. SILVA. 2008. Arqueología de asentamientos salitreros en la región de Antofagasta (1880-1930): síntesis y perspectivas. Chungará 40(1): 19-30.

VITALE, L. 1996. Cronología comentada del movimiento de mujeres en Chile. En Teoría y Práctica de la Escuela de Formación Sindical para Mujeres (Chile, 1993-1996), pp. 59-74. BUNSTIFT-Escuela de Formación Sindical para Mujeres, Santiago de Chile.

\section{Fuentes:}

Archivo Intendencia de Tarapacá ITAR. Libro Carabineros. Entrevistas: Archivo Hombres y Mujeres de la Pampa (1986-1990)

\section{Periódicos:}

La Hora del Norte de Antofagasta.

La Gaceta de Arica.

El Tarapacá de Iquique. 